\title{
Cyanidin-3-Glucoside inhibits ethanol-induced invasion of breast cancer cells overexpressing ErbB2
}

Mei Xu' ${ }^{1}$, Kimberly A Bower ${ }^{1}$, Siying Wang ${ }^{1,2}$, Jacqueline A Frank ${ }^{1}$, Gang Chen ${ }^{1}$, Min Ding ${ }^{3}$, Shiow Wang ${ }^{4}$, Xianglin Shi ${ }^{5}$, Zunji Ke ${ }^{6}$, Jia Luo ${ }^{1 *}$

\begin{abstract}
Background: Ethanol is a tumor promoter. Both epidemiological and experimental studies suggest that ethanol may enhance the metastasis of breast cancer cells. We have previously demonstrated that ethanol increased the migration/invasion of breast cancer cells expressing high levels of ErbB2. Amplification of ErbB2 is found in 20-30\% of breast cancer patients and is associated with poor prognosis. We sought to identify agents that can prevent or ameliorate ethanol-induced invasion of breast cancer cells. Cyanidin-3-glucoside (C3G), an anthocyanin present in many vegetables and fruits, is a potent natural antioxidant. Ethanol exposure causes the accumulation of intracellular reactive oxygen species (ROS). This study evaluated the effect of C3G on ethanol-induced breast cancer cell migration/invasion.

Results: C3G attenuated ethanol-induced migration/invasion of breast cancer cells expressing high levels of ErbB2 (BT474, MDA-MB231 and MCF7 ${ }^{\text {ErbB2}}$ ) in a concentration dependent manner. C3G decreased ethanol-mediated cell adhesion to the extracellular matrix (ECM) as well as the amount of focal adhesions and the formation of lamellipodial protrusion. It inhibited ethanol-stimulated phosphorylation of ErbB2, CSrc, FAK and p130 ${ }^{\text {Cas }}$, as well as interactions among these proteins. C3G abolished ethanol-mediated p130 Cas/JNK interaction.
\end{abstract}

Conclusions: C3G blocks ethanol-induced activation of the ErbB2/cSrc/FAK pathway which is necessary for cell migration/invasion. C3G may be beneficial in preventing/reducing ethanol-induced breast cancer metastasis.

\section{Background}

Excessive ethanol consumption is associated with an increased risk for breast cancer [1-5]. Epidemiological studies indicate that alcohol consumption is associated with advanced and invasive breast tumors [6,7]. We have previously demonstrated that breast cancer cells or mammary epithelial cells expressing high levels of ErbB2 are sensitive to ethanol-mediated migration/invasion; ethanol stimulates migration/invasion of breast cancers with high ErbB2 levels more robustly than cells expressing lower levels of ErbB2 [8-10]. ErbB2 belongs to the ErbB family of receptor kinases which consists of EGFR, ErbB2, ErbB3 and ErbB4. Among the ErbB family, ErbB2 is most directly related to breast cancer and is

\footnotetext{
* Correspondence: jialuo888@uky.edu

'Department of Internal Medicine, University of Kentucky College of Medicine, Lexington, KY 40536, USA Full list of author information is available at the end of the article
}

implicated in breast cancer metastasis. Amplification of ErbB2 is found in $20-30 \%$ of breast cancer patients and is associated with poor prognosis and relapse $[11,12]$.

We sought to identify agents that may ameliorate ethanol's promoting effect on breast cancer cell migration/invasion. Cyanidin-3-glucoside (C3G) is a member of the anthocyanin family which is present in various vegetables and fruits, especially edible berries. C3G is a potent antioxidant and displays anti-cancer properties in vitro and in vivo [13-18]. Since ethanol exposure causes the accumulation of intracellular oxygen species (ROS) and many biological effects of ethanol are believed to be mediated by ROS, we hypothesize that C3G may inhibit ethanol-induced migration/invasion of breast cancer cells. We examined the effect of C3G on ethanolmediated migration/invasion of breast cancer cells expressing high levels of ErbB2. We demonstrate here that C3G effectively blocks ethanol-induced cell
Ciomed Central 
migration/invasion. We further investigate the effect of C3G on the cell/extracellular matrix (ECM) interaction and the associated ErbB2/cSrc/FAK pathway.

\section{Materials and methods Materials}

Human plasma fibronectin was obtained from Chemicon International (Temecula, CA). Anti-paxillin antibody was purchased from Invitrogen Corporation (Carlsbad, CA). Anti-phospho-ErbB2 (Tyr1248) (polyclonal), phospho-p130 ${ }^{\mathrm{Cas}}$ and ErbB2 (polyclonal) antibodies were purchased from Cell Signaling Technology Inc. (Beverly, MA). Anti-Neu/Her2/ErbB2 (monoclonal), FAK, cSrc, JNK and phospho-Src (Tyr216) antibodies and Protein A/G beads were purchased from Santa Cruz Biotechnology (San Diego, CA). Anti-phospho-Her2/ ErbB2 (Tyr1248) (monoclonal) and phospho-FAK (Tyr861) antibodies were purchased from Biosource (Camarillo, CA). Anti-p130 ${ }^{\text {Cas }}$ antibody was obtained from BD Transduction Laboratory (San Jose, CA). Antiactive JNK antibody was obtained from Promega Corporation (Madison, WI). Phalloidin 488, Alex Fluorlabeled secondary antibodies, Prolong Gold anti-fade reagent and reactive oxygen species detection reagents were obtained from Invitrogen Molecular Probes (Eugene, OR). MTT assay kit was purchased from Roche Molecular Biochemicals (Indianapolis, IN). Matrigel Invasion Chambers were purchased from BD Biosciences (Bedford, MA). Transwell was obtained from Costar Corp. (Acton, MA). C3G was purified from blackberry fruit tissue as previously described [14]. The purity of C3G is greater than 95\%. Alcohol (200 Proof) was obtained from Fisher Scientific (Pittsburgh, PA). All other chemicals were obtained from Sigma-Aldrich (St. Louis, MO).

\section{Cell culture and ethanol exposure}

MCF7 $^{\text {ErbB2 }}$ (MCF7 cells overexpressing ErbB2) and MDA-MB231 breast cancer cells were grown in DMEM medium containing $10 \%$ fetal bovine serum (FBS), penicillin $(100 \mathrm{U} / \mathrm{ml}) /$ streptomycin $(100 \mathrm{U} / \mathrm{ml}), 1 \mu \mathrm{g} / \mathrm{ml}$ hydrocortisone and $10 \mu \mathrm{g} / \mathrm{ml}$ insulin at $37^{\circ} \mathrm{C}$ with $5 \%$ $\mathrm{CO}_{2}$. BT474 cells were grown in RPMI 1640 medium containing $10 \% \mathrm{FBS}$, penicillin $(100 \mathrm{U} / \mathrm{ml}) /$ streptomycin $(100 \mathrm{U} / \mathrm{ml})$ and $10 \mu \mathrm{g} / \mathrm{ml}$ insulin. A method utilizing sealed containers was used to maintain ethanol concentrations in the culture medium. The containers were placed in a humidified environment and maintained at $37^{\circ} \mathrm{C}$ with $5 \% \mathrm{CO}_{2}$.

\section{Cell invasion and migration}

Cell invasion was assayed using Matrigel Invasion Chambers (BD Biosciences). Briefly, cells were placed on the upper compartment of invasion chambers and treated with ethanol in the presence or absence of C3G. Culture medium containing 10\% FBS was added into the lower compartment of invasion chambers and served as chemoattractants for the cells. Cells were maintained in the invasion chambers for 48 hours. The invaded cells were fixed in $3.7 \%$ paraformaldehyde and stained with $0.5 \%$ crystal violet in $2 \%$ ethanol. Membranes were washed and the dye was eluted with $10 \%$ acetic acid. Absorbance was measured at $595 \mathrm{~nm}$ using a microtiter platereader (Beckman coulter).

Cell migration was analyzed using a Transwell Migration System (Costar). Briefly, cells were plated into upper chambers (Transwells with $8.0 \mu \mathrm{m}$ pore size) in serum free medium. The lower compartment of the chamber contained regular medium containing $10 \%$ FBS. The chambers were cultured at $37^{\circ} \mathrm{C}$ in $5 \% \mathrm{CO}_{2}$ for 12 hours. Migrated cells were fixed and stained with $0.5 \%$ crystal violet, followed by dye elution and absorbance measurement as described above.

\section{Wound healing migration assay}

The wound healing migration assay was performed as described previously [14]. MDA-MB231 cells were grown on $35 \mathrm{~mm}$ dishes to $100 \%$ confluence and then scratched to form a wound using sterile pipette tips. The cells were then treated with ethanol $(0$ or $400 \mathrm{mg} /$ $\mathrm{dl})$ in the presence or absence of C3G $(10 \mu \mathrm{M})$ for 24 hours. The images were recorded using a Zeiss Axiovert 40C photomicroscope.

\section{Analysis of cell adhesion}

Cell adhesion to fibronectin was analyzed as described previously [19-21]. Briefly, 96-well cell culture plates were precoated with fibronectin $(10 \mu \mathrm{g} / \mathrm{ml})$ for $60 \mathrm{~min}$ at $37^{\circ} \mathrm{C}$. Plates were then incubated with $3 \%$ BSA in PBS for $30 \mathrm{~min}$ to block non-specific binding sites, followed by several washes with PBS. Cells were exposed to ethanol with/without C3G for 48 hours. After exposure, cells $\left(5 \times 10^{4} /\right.$ well $)$ were seeded on fibronectin precoated plates, allowing attachment for 1 hour at $37^{\circ} \mathrm{C}$ with $5 \% \mathrm{CO}_{2}$. Non-adherent cells were removed by washing with PBS. The attached cells were fixed with $3.7 \%$ paraformaldehyde for $10 \mathrm{~min}$, washed 3 times in PBS, and stained with $0.1 \%$ crystal violet in $2 \%$ ethanol for $10 \mathrm{~min}$. Cells were rinsed with water and dried. Crystal violet was eluted in 10\% acetic acid and the absorbance (attached cells) was measured at $595 \mathrm{~nm}$ using a microtiter platereader.

\section{MTT assay}

The MTT assay was employed to determine the number of viable cells in culture. Briefly, the cells were plated into 96-well plates and exposed to ethanol with/without C3G for indicated times. After the treatment, $10 \mu \mathrm{l}$ of 
MTT reagent was added into each well and the plates were incubated at $37^{\circ} \mathrm{C}$ for 4 hours. The cultures were solubilized and spectrophotometric absorbance was measured at $595 \mathrm{~nm}$ using a microtiter platereader.

\section{Immunofluorescence microscopy}

The procedure for immunofluorescence microscopy has been previously described [22]. Briefly, after treatments, cells were seeded on fibronectin $(10 \mu \mathrm{g} / \mathrm{ml})$ precoated coverslips. Cells were fixed with $3.7 \%$ paraformaldehyde for $10 \mathrm{~min}$, washed 3 times in PBS and permeabilized with $0.5 \%$ Triton X-100 for 5 min. Cells were blocked with 5\% BSA and incubated with primary antibodies for 1 hour. The concentrations of primary antibodies were: phospho-FAK (Tyr861), 1:50; paxillin, 1:800; and phalloidin, 1:200. Following incubation with primary antibodies, cells were washed and treated with Alexa Fluorlabeled secondary antibodies and rinsed several times with PBS. Coverslips were mounted with Prolong Gold anti-fade reagent and immunofluorescence images were examined with a LEICA SP1 inverted confocal microscope. The fluorescent signals were measured with the same pinhole, detector gain and amplifier offset. The focal adhesions were detected by immunostaining for phosphorylated FAK and quantified randomly on 10 or more cells for each treatment condition.

\section{Immunoprecipitation and immunoblotting}

After the treatment of ethanol and/or C3G, cells were trypsinized and seeded on fibronectin $(10 \mu \mathrm{g} / \mathrm{ml})$ precoated dishes allowing attachment for indicated times. Cells were then rinsed twice in cold PBS to remove non-adherent cells. Attached cells were lysed in modified RIPA buffer $(150 \mathrm{mM} \mathrm{NaCl}, 50 \mathrm{mM}$ Tris, $1 \% \mathrm{NP}$ 40, $0.25 \%$ sodium deoxycholate, $1 \mathrm{mM}$ sodium vanadate, $1 \mathrm{mM}$ phenylmethanesulfonyl fluoride (PMSF), $5 \mu \mathrm{g} / \mathrm{ml}$ of aprotinin, and $2 \mu \mathrm{g} / \mathrm{ml}$ of leupeptin). The procedure for immunoprecipitation and immunoblotting has been previously described $[10,19]$. Briefly, equal amounts of proteins (about $500-800 \mu \mathrm{g}$ ) were incubated with antiErbB2, FAK, p130 ${ }^{\mathrm{Cas}}$ or cSrc antibodies overnight at $4^{\circ}$ $\mathrm{C}$, followed by treatment with TrueBlot anti-mouse Ig or anti-rabbit Ig beads (eBioscience, San Diego, CA) for 2 hours at $4^{\circ} \mathrm{C}$. Immunoprecipitates were collected by centrifugation at $10,000 \mathrm{~g}$ for $5 \mathrm{~min}$ at $4^{\circ} \mathrm{C}$. Samples were washed five times with RIPA buffer, one time with cold PBS and boiled in sample buffer $(187.5 \mathrm{mM}$ Tri$\mathrm{HCl}, \mathrm{pH} 6.8$, 6\% SDS, 30\% glycerol, $150 \mathrm{mM}$ DTT and $0.03 \%$ bromophenol blue). Proteins were resolved in SDS-PAGE and the separated proteins were transferred to nitrocellulose membranes. The membranes were probed with indicated primary antibodies, followed by the appropriate TrueBlot horseradish peroxidase- conjugated secondary antibodies and developed by enhanced chemiluminescence.

\section{Detection of intracellular reactive oxygen species}

Intracellular reactive oxygen species (ROS) levels were measured using the fluorescent dye CM- $\mathrm{H}_{2}$ DCFDA (Invitrogen Corporation, Carlsbad, CA) as previously described [23]. CM- $\mathrm{H}_{2}$ DCFDA is converted to a nonfluorescent derivative inside the cells and when oxidized forms a highly fluorescent product by intracellular ROS. Briefly, cells were treated with ethanol with/without C3G or other antioxidants for 48 hours. After the treatment, cells were washed with cold PBS and incubated with $5 \mu \mathrm{M} \mathrm{CM}-\mathrm{H}_{2}$ DCFDA for $30 \mathrm{~min}$, followed by several additional washes with cold PBS. Cells were trypsinized and transferred into polystyrene round-bottom tubes; intracellular ROS levels were measured with a flow cytometer (FACScalibur, BD Biosciences, San Jose, CA) at an emission wavelength of $525 \mathrm{~nm}$.

\section{Statistics}

Differences among treatment groups were analyzed using analysis of variance (ANOVA). Differences in which $p$ was less than 0.05 were considered statistically significant. In cases where significant differences were detected, specific post-hoc comparisons between treatment groups were examined with Student-NewmanKeuls tests.

\section{Results}

\section{C3G inhibits ethanol-enhanced migration/invasion and} attachment of breast cancer cells

We have previously demonstrated that the effect of ethanol on the migration/invasion of breast cancer cells is positively associated with their expression levels of ErbB2 [8-10]. The current study confirmed the finding and showed that ethanol increased the migration/invasion of MCF7 ${ }^{\mathrm{ErbB} 2}$, BT474 and MDA-MB231 breast cancer cells (Figure 1). C3G (10-40 $\mu \mathrm{M})$ significantly inhibited ethanol-enhanced migration/invasion of $\mathrm{MCF}^{\mathrm{ErbB} 2}$ and MDA-MB231 in a concentration dependent manner (Figures 1B-D). C3G-mediated inhibition was statistically different among the three C3G concentrations tested. The effect of C3G on BT474 cells, however, was not dose-dependent (Figure 1D). C3G alone at $10 \mu \mathrm{M}$ did not affect the invasion of MCF7 ${ }^{\mathrm{ErbB} 2}$ cells (Figure 1A). For BT474 and MDA-MB231 cells, C3G alone produced a modest but statistically significant inhibition of cell invasion (data not shown). The inhibitory effect of C3G on ethanol-induced cell migration was confirmed by a wound healing migration assay (Figure $1 \mathrm{~F}$ ). The MTT assay showed that even $40 \mu \mathrm{M}$ C3G did not affect the viability of BT474, MDA-MB231 and 


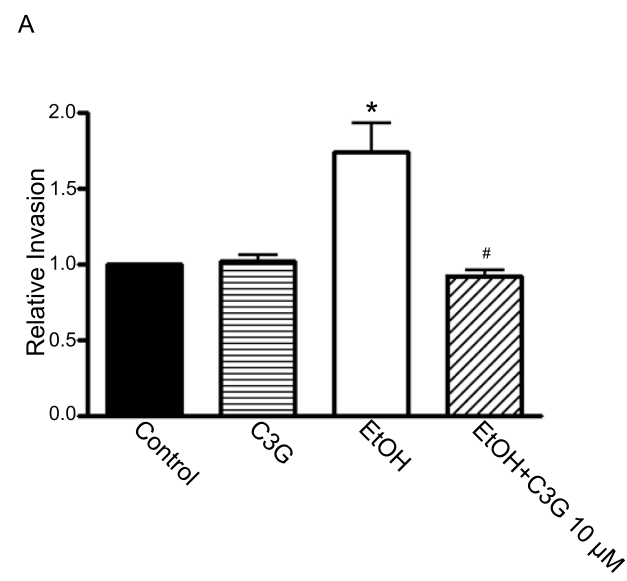

C

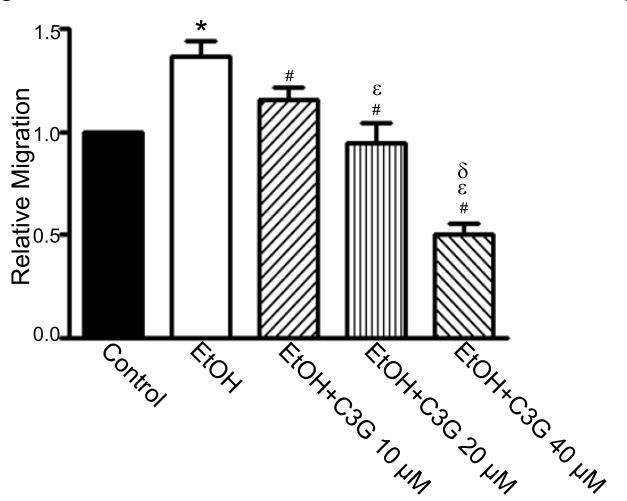

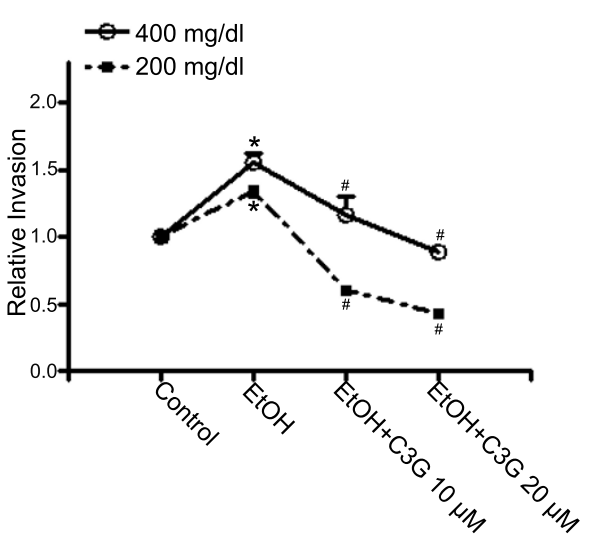

D

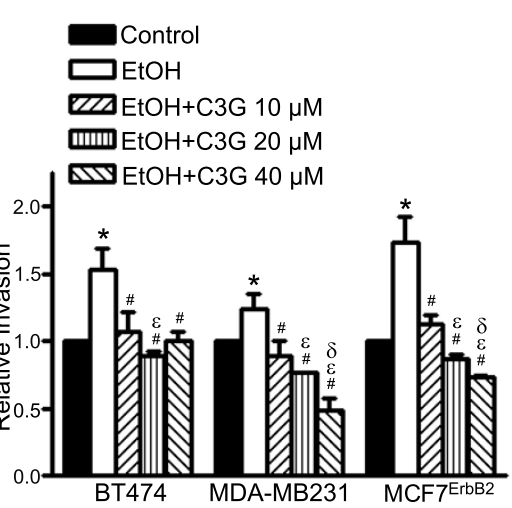

E

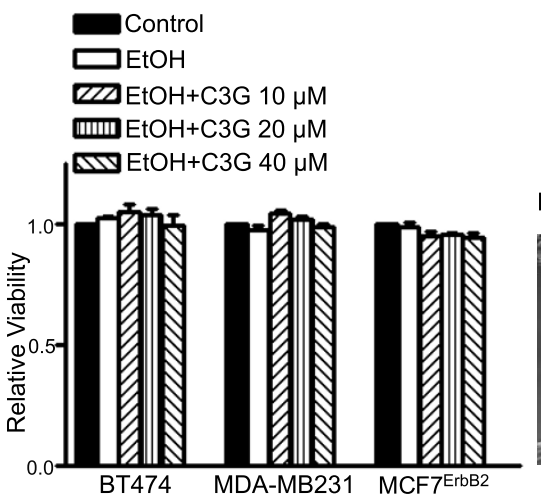

$\mathrm{F}$
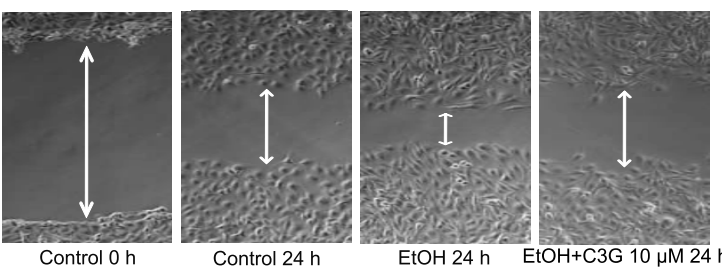

Figure 1 Effects of C3G on ethanol-mediated invasion/migration of breast cancer cells. A: MCF7 ${ }^{\text {ErbB2 }}$ cells were plated into the upper compartments of the matrigel invasion chambers and exposed to ethanol ( 0 or $400 \mathrm{mg} / \mathrm{dl}$ ) with/without C3G (10 $\mu \mathrm{M})$ for $48 \mathrm{~h}$. Following the treatment, the invasive potential was assayed as described under the Materials and Methods and presented relative to untreated controls. B: MCF7 ${ }^{\text {ErbB2 }}$ cells were exposed to ethanol $(0,200$ or $400 \mathrm{mg} / \mathrm{dl})$ with/without C3G (10 or $\left.20 \mu \mathrm{M}\right)$ for $48 \mathrm{~h}$. The invasive potential was assayed as described above. C: MCF7 $7^{\text {ErbB2 }}$ cells were plated into the upper compartments of the migration chamber and exposed to ethanol $(0$ or 400 $\mathrm{mg} / \mathrm{dl}$ ) with/without C3G (10, 20 or $40 \mu \mathrm{M})$ for $12 \mathrm{~h}$. The migration was analyzed as described under the Materials and Methods and presented relative to untreated controls. D: BT474, MDA-MB231 or MCF7 7 ErbB2 cells were exposed to ethanol (0 or $400 \mathrm{mg} / \mathrm{dl}$ ) with/without C3G (10, 20 or $40 \mu \mathrm{M})$ for $48 \mathrm{~h}$. Their invasion potential was evaluated as described above. E: BT474, MDA-MB231 or MCF7 ${ }^{\text {ErbB2 }}$ cells were exposed to ethanol ( 0 or $400 \mathrm{mg} / \mathrm{dl}$ ) with/without C3G (10,20 or $40 \mu \mathrm{M}$ ) for $48 \mathrm{~h}$ and cell viability was determined with MTT assay. The number of viable cells was presented relative to untreated controls. Each datum point was the mean \pm SEM of three independent experiments. * denotes a statistically significant difference from untreated controls. \# denotes a significant difference from ethanol-treated groups. $\varepsilon$ denotes a significant difference from ethanol- and C3G (10 $\mu \mathrm{M})$-treated groups. $\delta$ denotes a significant difference from ethanol- and C3G (20 $\mu \mathrm{M})$-treated groups. F: MDA-MB231 cells were exposed to ethanol (0 or $400 \mathrm{mg} / \mathrm{dl}$ ) with/without C3G $(10 \mu \mathrm{M})$ for $24 \mathrm{~h}$ and cell migration was determined by wound healing migration assay as described under the Materials and Methods. 
$\mathrm{MCF}^{\mathrm{ErbB} 2}$ cells (Figure 1E). However, at $100 \mu \mathrm{M}$ or above, C3G did decrease cell viability (data not shown).

The adhesion of cancer cells to ECM or cell/ECM interaction is an important step of metastasis. We have previously demonstrated that ethanol enhances the adhesion of breast cancer cells to fibronectin, an essential protein in the ECM [19]. Ethanol did not affect the attachment of breast cancer cells to poly-lysine (data not shown). We examined the effect of C3G on ethanolmediated cell adhesion to fibronectin. MCF7 ${ }^{\text {ErbB2 }}$ cells were pretreated with ethanol with/without C3G for 48 hours, then the cells were seeded on fibronectin precoated plates and allowed to attach for 1 hour in the presence/absence of ethanol and/or C3G. As shown in Figure 2, ethanol increased the adhesion of MCF7 ${ }^{\mathrm{ErbB} 2}$ cells to fibronectin and C3G significantly inhibited ethanol-enhanced adhesion in a concentration-dependent manner. C3G alone (10-20 $\mu \mathrm{M})$ did not affect cell adhesion (data not shown). C3G similarly inhibited ethanolinduced adhesion of MDA-MB231 cells to the ECM (data not shown).

\section{C3G attenuates ethanol-stimulated ErbB2 signaling}

We have previously shown that ethanol increased the phosphorylation of ErbB2 at Tyr1248 [19]. In this study, we examined the effect of $\mathrm{C} 3 \mathrm{G}$ on ethanol-mediated ErbB2 phosphorylation. MDA-MB231 and MCF7 ${ }^{\text {ErbB2 }}$

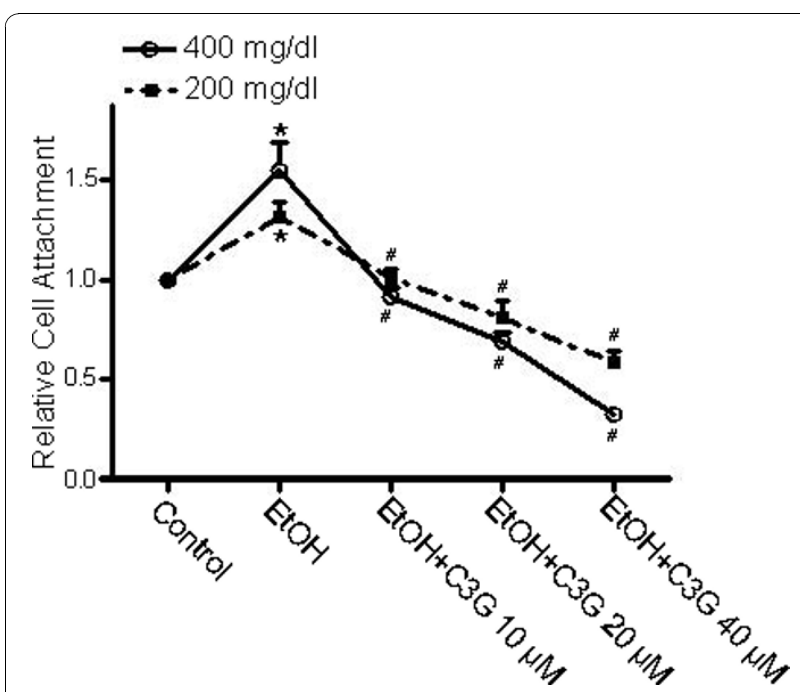

Figure 2 Effects of C3G on ethanol-mediated adhesion of breast cancer cells. MCF $7^{\text {ErbB2 }}$ cells were treated with ethanol $(0$, 200 or $400 \mathrm{mg} / \mathrm{dl}$ ) with/without C3G (10, 20 or $40 \mu \mathrm{M})$ for $48 \mathrm{~h}$, and then equal amounts of cells were seeded on fibronectin-coated culture wells, allowing attachment for $1 \mathrm{~h}$. The number of adherent cells was determined as described under the Materials and Methods and presented relative to untreated controls. Each datum point was the mean \pm SEM of three independent experiments. ${ }^{*}$ denotes a statistically significant difference from untreated controls. \# denotes a significant difference from ethanol-treated groups. cells were pretreated with ethanol with/without C3G for 48 hours, then cells were seeded into fibronectin precoated dishes, allowing attachment for 3 hours. As shown in Figure 3, ethanol drastically increased the phosphorylation of ErbB2 [p-ErbB2(Tyr1248)] in these cells. The addition of C3G attenuated ethanol-stimulated p-ErbB2(Tyr1248) in a concentration-dependent manner. The cSrc/FAK pathway plays an important role in ErbB2-regulated migration/invasion of breast cancer cells [24]. FAK is a substrate of cSrc and FAK Tyr861 is a major site of phosphorylation by cSrc. As shown in Figure 3, ethanol increased the levels of p-FAK(Tyr861) and p-cSrc(Tyr216). C3G attenuated ethanol-induced pFAK(Tyr861) and p-cSrc(Tyr216). The activation and phosphorylation of $\mathrm{cSrc} / \mathrm{FAK}$ is critical for triggering its downstream signaling and for recruiting proteins to the focal adhesion sites. p130 ${ }^{\text {Cas }}$, an adaptor protein, binds to the C-terminal site of FAK, forming a dock site for Crk; $\mathrm{p} 130^{\mathrm{Cas}} / \mathrm{Crk}$ interaction induces the activation of small GTPases and JNKs, promoting membrane protrusion and cell migration $[25,26]$. The phosphorylation of $\mathrm{p} 130^{\mathrm{Cas}}$ is regulated by FAK and cSrc [27]. We demonstrated that ethanol induced the phosphorylation of p130 ${ }^{\text {Cas }}$ [p-p130 $\left.{ }^{\mathrm{Cas}}(\mathrm{Tyr} 410)\right]$, and C3G blocked ethanolinduced p-p130 ${ }^{\mathrm{Cas}}$ (Tyr410) (Figure 3A). We further examined the effect of $\mathrm{C} 3 \mathrm{G}$ on the interaction among ErbB2, cSrc, FAK and p130 ${ }^{\text {Cas }}$. MCF7 ${ }^{\text {ErbB2 }}$ cells were treated with ethanol or with/without C3G for 48 hours and seeded on fibronectin for 1 or 3 hours. As shown in Figure 4, ethanol increased the association between ErbB2/FAK, FAK/cSrc, FAK/p130 ${ }^{\text {Cas }}$ and $\mathrm{cSrc} / \mathrm{p} 130^{\mathrm{Cas}}$. C3G abolished the interaction among these proteins (Figure 4). These data indicated that C3G inhibited the ethanol-activated ErbB2/cSrc/FAK pathway.

c-Jun N-terminal kinases (JNKs), a member of mitogen-activated protein kinases (MAPKs), regulate cell migration/invasion [28]. We have previously demonstrated that JNKs are essential for ethanol-mediated cell invasion/migration [10]. JNK activation is regulated by p130 ${ }^{\text {Cas }}$ [27]. C3G inhibited ethanol-induced JNK phosphorylation and $\mathrm{p} 130^{\mathrm{Cas}} / \mathrm{JNK}$ association in MCF7 ${ }^{\mathrm{ErbB} 2}$ cells (Figure 5).

\section{C3G inhibits ethanol-induced formation of lamellipodia and focal adhesions}

The initiation of cell migration requires the development of membrane protrusion, the lamellipodium and the assembly of dynamic focal adhesions with the ECM [29]. We sought to determine whether C3G affected the formation of the lamellipodium and focal adhesions. We used MDA-MB231 cells for this experiment because these cells displayed more prominent lamellipodium and focal adhesions during the migration process. Figure 6A shows that actin filament distribution was concentrated 


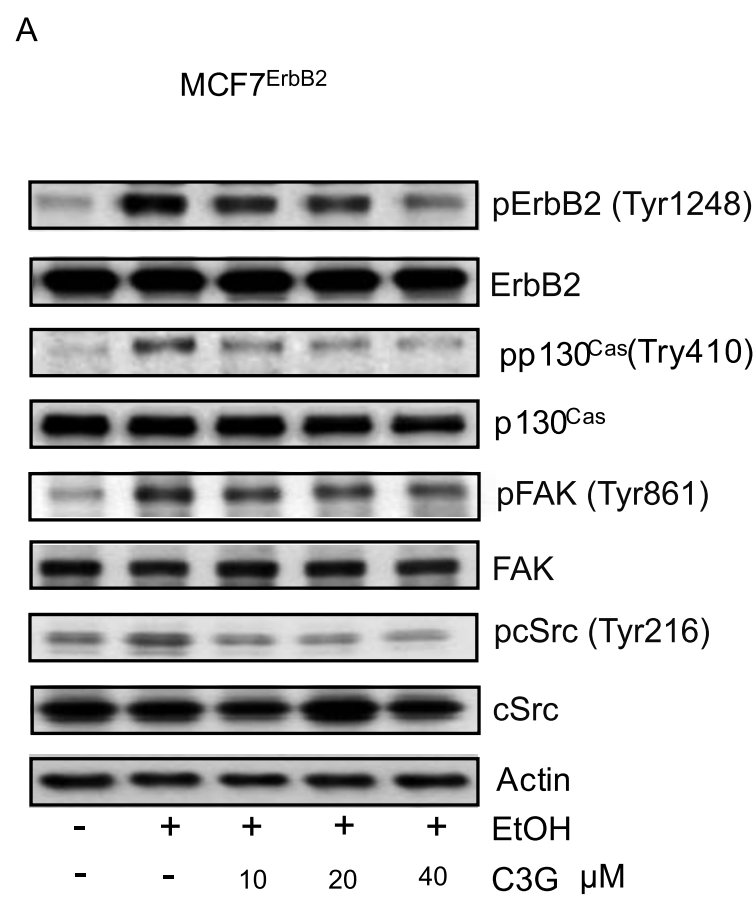

B

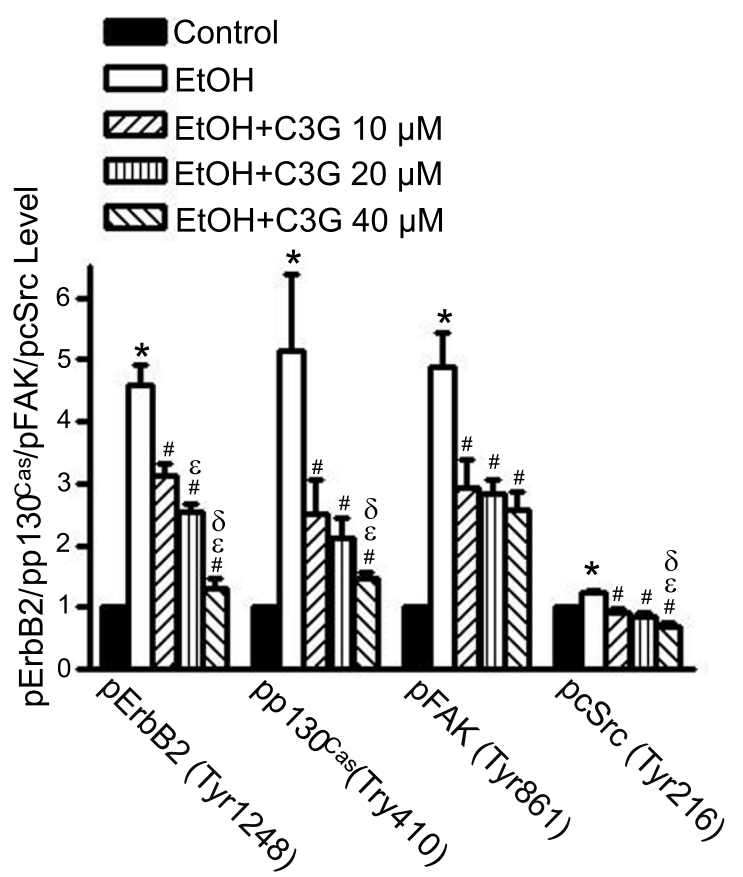

$B$
C

MDA-MB231

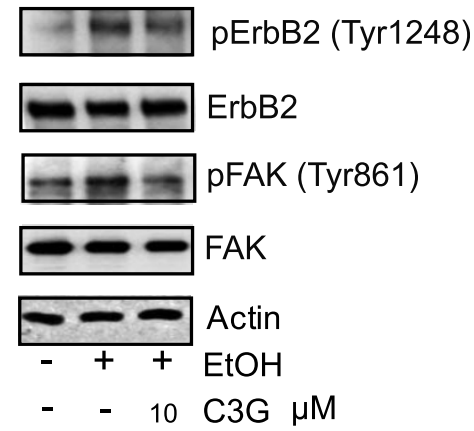




\section{A IP: ErbB2}

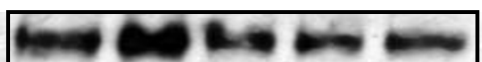

IB: FAK

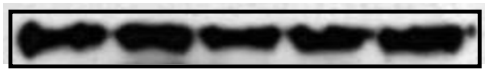

IB: ErbB2

$-++++\mathrm{EtOH}$

- $\quad 1020 \quad 40$ C3G $\mu \mathrm{M}$

C

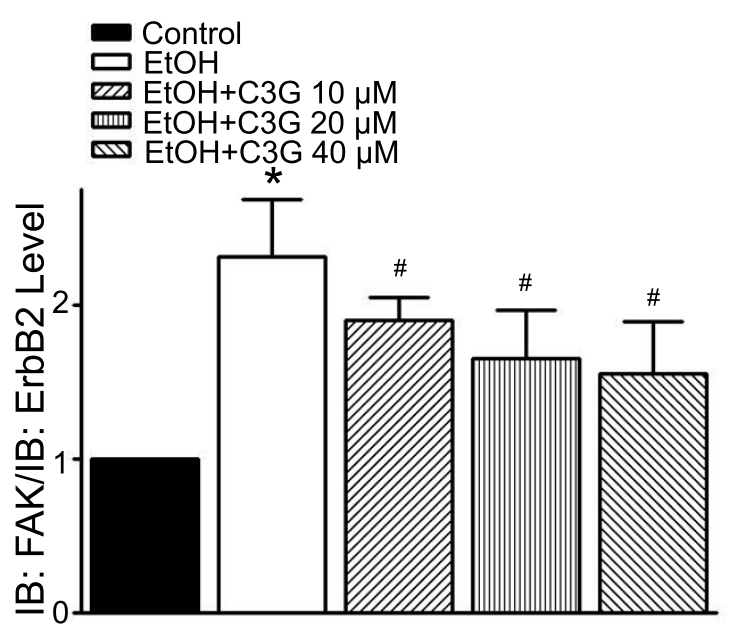

B IP: $p 130^{\text {Cas }}$
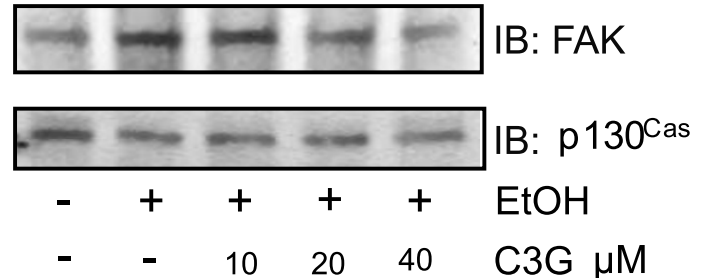

D

Control

EtOH

EtOH+C3G $10 \mu \mathrm{M}$

띠 EtOH+C3G $20 \mu \mathrm{M}$

$\mathrm{EtOH}+\mathrm{C} 3 \mathrm{G} 40 \mu \mathrm{M}$

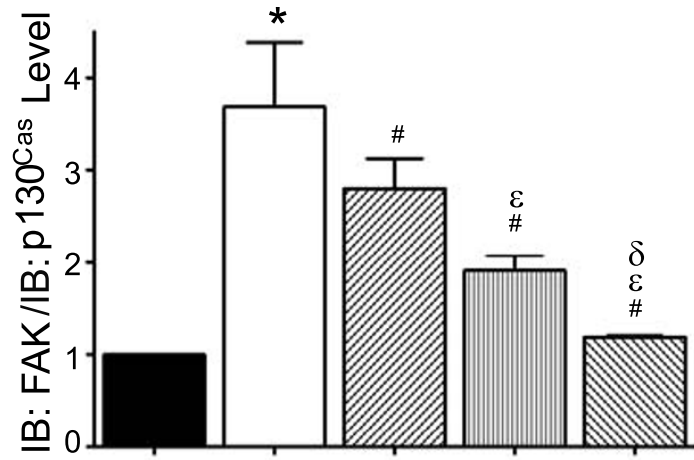

E IP: cSrc

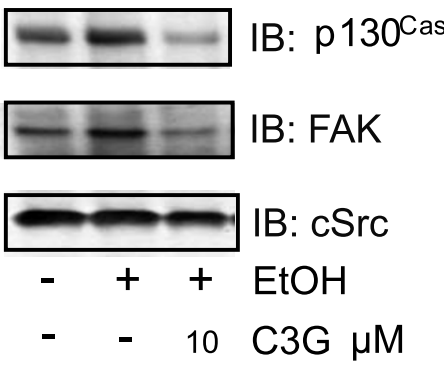

Figure 4 Effects of C3G on the interaction among ErbB2, FAK, cSrc and p130 ${ }^{\text {Cas }}$. MCF $7^{\text {ErbB2 }}$ cells were treated with ethanol $(0$ or $400 \mathrm{mg} /$ dl) with/without C3G (10, 20 or $40 \mu \mathrm{M})$ for $48 \mathrm{~h}$. Cells were plated on fibronectin-coated culture wells. A: After $1 \mathrm{~h}$ of attachment on fibronectin, cell lysates were collected and immunoprecipitated (IP) with an anti-ErbB2 antibody, then immunoblotted (IB) with either an anti-FAK or antiErbB2 antibody. B: After $3 \mathrm{~h}$ of attachment, cell lysates were IP with an anti-cSrc antibody and IB with either an anti-p130 Cas , FAK or cSrc antibody. C and D: The association between ErbB2 and FAK (panel A) and the association between FAK and p130 Cas (panel B) was quantified by densitometry. * denotes a statistically significant difference from untreated controls. \# denotes a significant difference from ethanol-treated groups. $\varepsilon$ denotes a significant difference from ethanol- and C3G $(10 \mu \mathrm{M})$-treated groups. $\delta$ denotes a significant difference from ethanol- and C3G (20 $\mu \mathrm{M})$-treated groups. E: After $3 \mathrm{~h}$ of attachment, cell lysates were IP with an anti-p130 ${ }^{\text {Cas }}$ antibody and IB with either an anti-FAK or antip130 ${ }^{\text {Cas }}$ antibody. The experiment was replicated three times. 


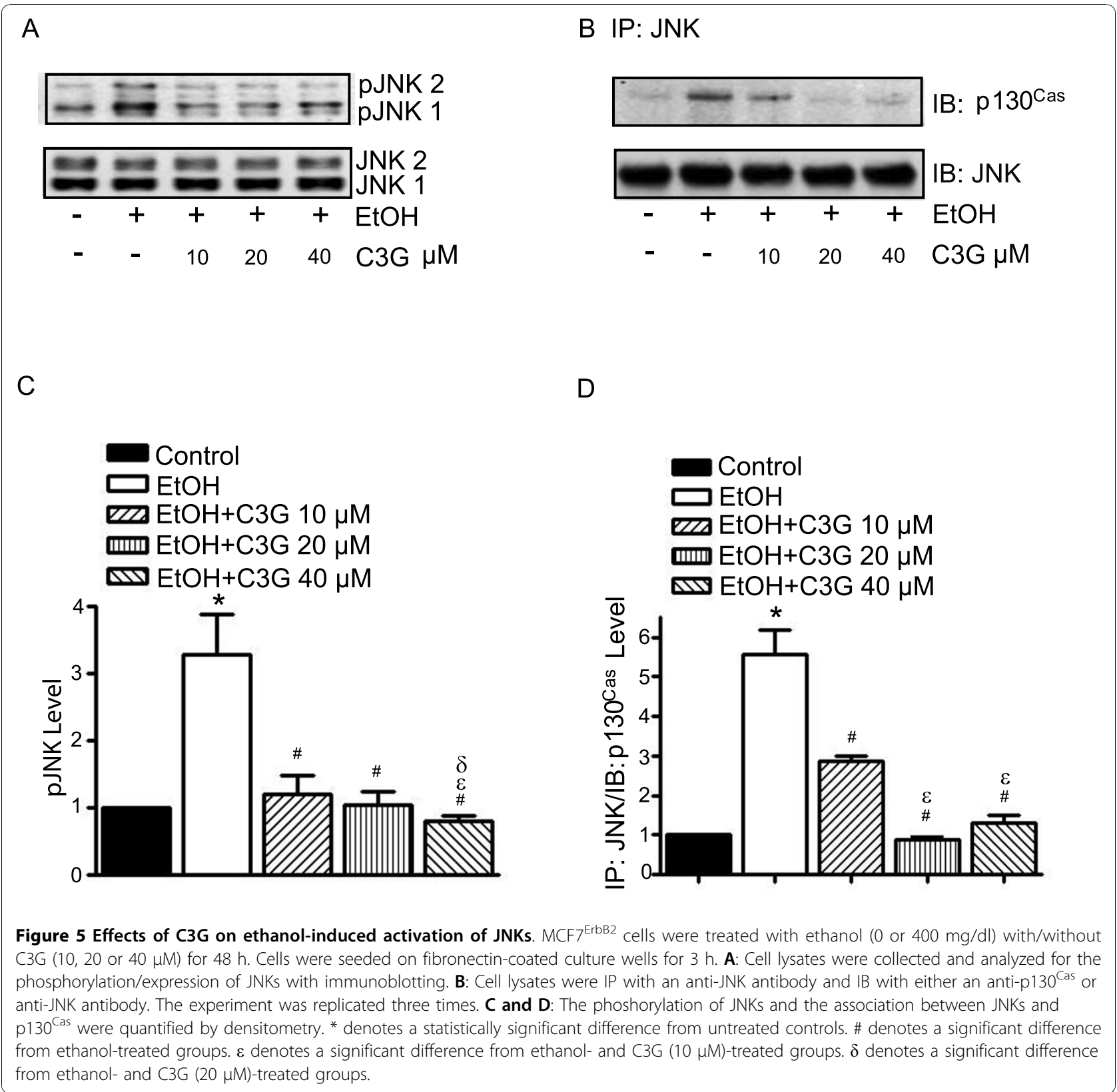

at the leading edge/lamellipodia in ethanol-treated MDA-MB231 cells. Ethanol caused an approximate 3fold increase in the number of lamellipodia (Figure 6B). C3G inhibited ethanol-induced lamellipodia formation; however, the inhibition was not concentration-dependent and C3G at 10 or $40 \mu \mathrm{M}$ had a similar effect (Figure $6 \mathrm{~B})$. We demonstrated an accumulation of p-FAK (Tyr861) at the leading area in ethanol-treated cells (Figures $6 \mathrm{~A}$ and 7A). Ethanol also caused redistribution of paxillin, and more paxillin was localized at the leading edge following ethanol exposure (Figure 7A). Since the activation of FAK leads to the recruitment of paxillin and $\mathrm{p} 130^{\mathrm{Cas}}$ to focal adhesion sites $[27,30]$, we examined the effect of ethanol on focal adhesions. Ethanol enhanced the assembly of focal adhesions and C3G significantly inhibited ethanol-induced formation of focal adhesions (Figure 7B).

\section{C3G scavenges ethanol-induced accumulation of reactive oxygen species (ROS)}

Ethanol causes intracellular accumulation of reactive oxygen species (ROS) and induces oxidative stress $[10,31]$. Since C3G is a potent antioxidant, the inhibitory effect of C3G on ethanol-induced migration/invasion may be mediated by its antioxidant property. We evaluated the effect of other antioxidants at concentrations 


\section{A}
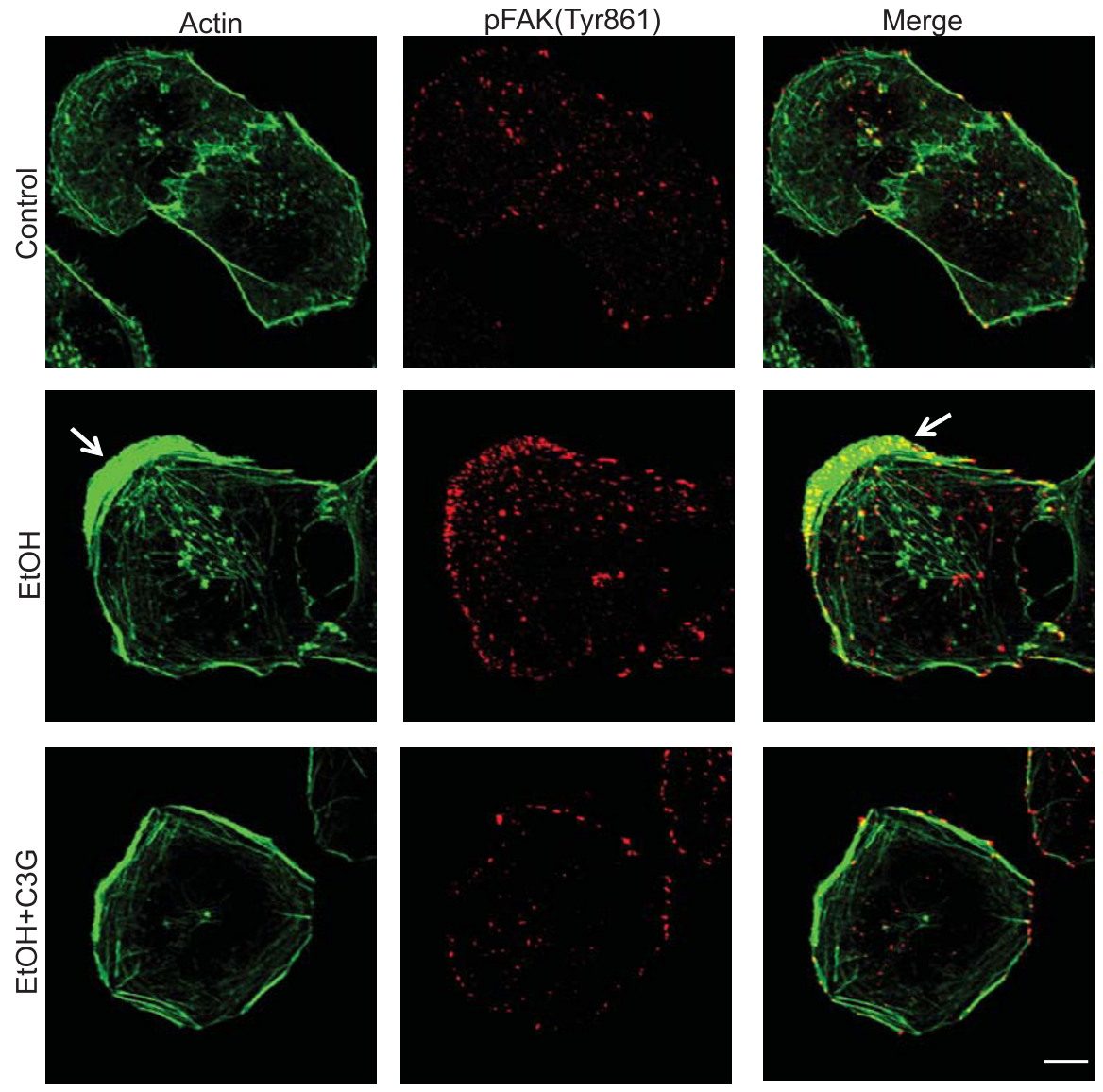

B

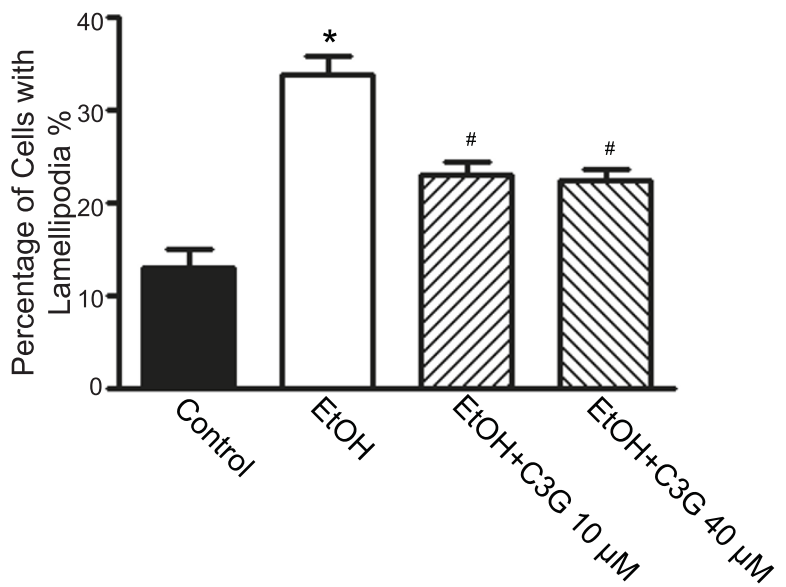

Figure 6 Effects of C3G on the development of lamellipodia. MDA-MB231 cells were treated with ethanol $(0 \mathrm{or} 400 \mathrm{mg} / \mathrm{dl})$ with/without C3G $(10$ or $40 \mu \mathrm{M})$ for $48 \mathrm{~h}$. Cells were seeded on fibronectin-coated coverslips for $3 \mathrm{~h}$. A: The expression of actin (Alexa Fluor 488 Phalloidin) and phosphorylated FAK (Tyr 861) (Alexa Flour 594) were detected with immunofluorescent staining. The arrow indicates lamellipodia. Scale bar $=5 \mu \mathrm{m}$. B: Cells with extended leading areas (lamellipodia) were counted in ten randomly selected fields in each treatment group. The percentage of cells with lamellipodia was determined. The experiment was replicated three times. ${ }^{*}$ denotes a significant difference from untreated controls. \# denotes a significant difference from ethanol-treated groups. 

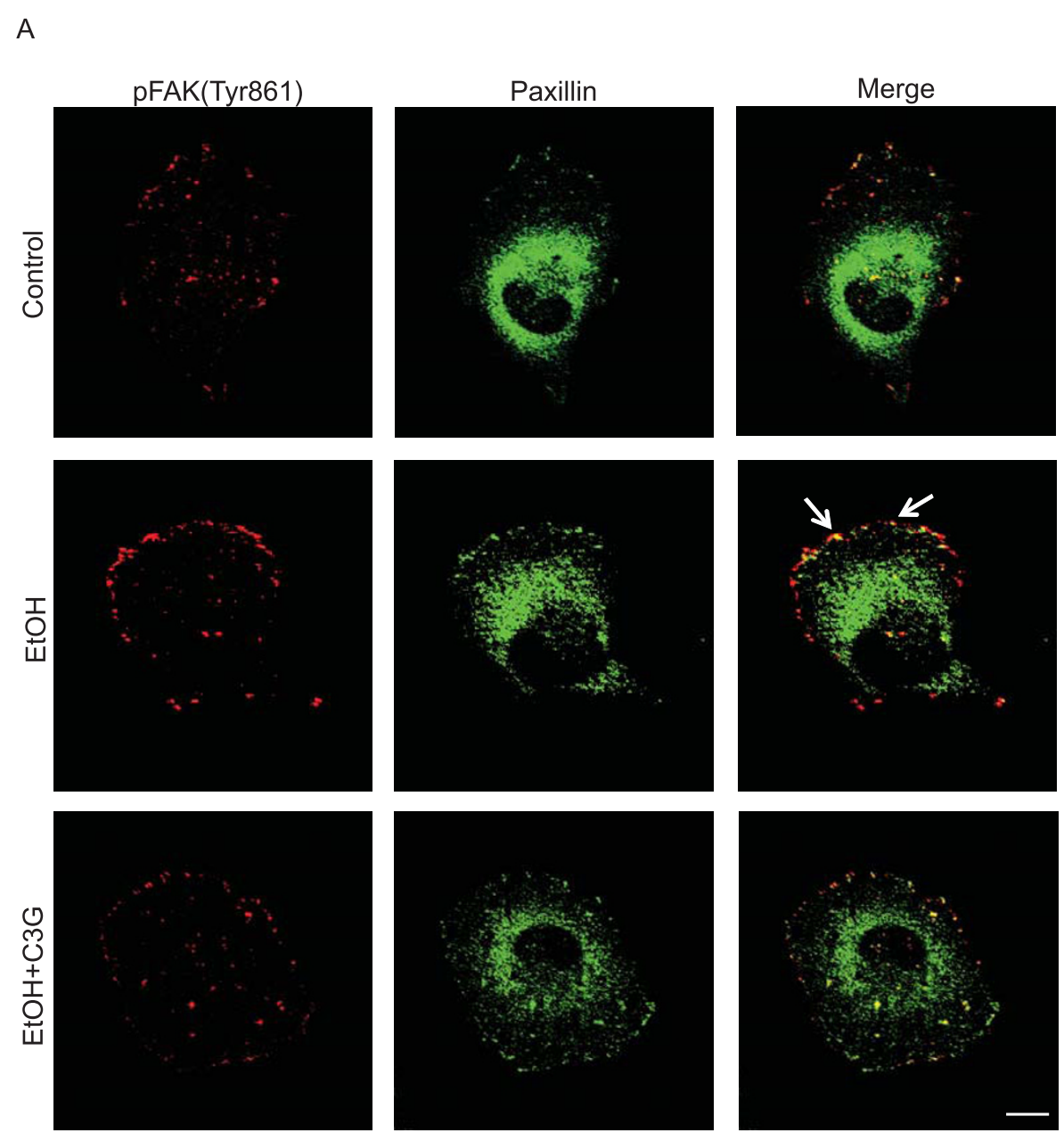

B

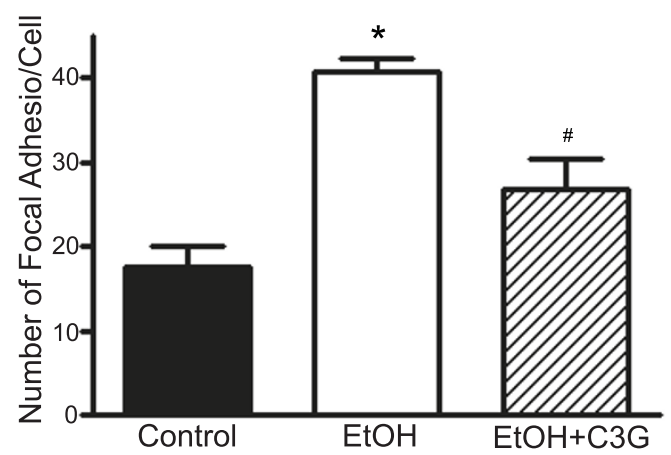

Figure 7 Effects of C3G on ethanol-mediated formation of focal adhesions. MDA-MB231 cells were treated with ethanol $(0 \mathrm{or} 400 \mathrm{mg} / \mathrm{dl})$ with/without C3G (40 $\mu \mathrm{M})$ for $48 \mathrm{~h}$. Cells were seeded on fibronectin-coated coverslips for $3 \mathrm{~h}$. A: The expression of paxillin (Alexa Fluor 488) and phosphorylated FAK (Tyr861) (Alexa Fluor 594) were detected by immunofluorescent staining. Arrows indicate the co-localization of p-FAK (Tyr861) and paxillin. Scale bar $=5 \mu \mathrm{m}$. B. Focal adhesions were counted randomly on 10 or more cells. The number of focal adhesions per cell was calculated. Each datum point was the mean \pm SEM of three independent experiments. ${ }^{*}$ denotes a significant difference from untreated controls. \# denotes a significant difference from ethanol-treated groups. 
A

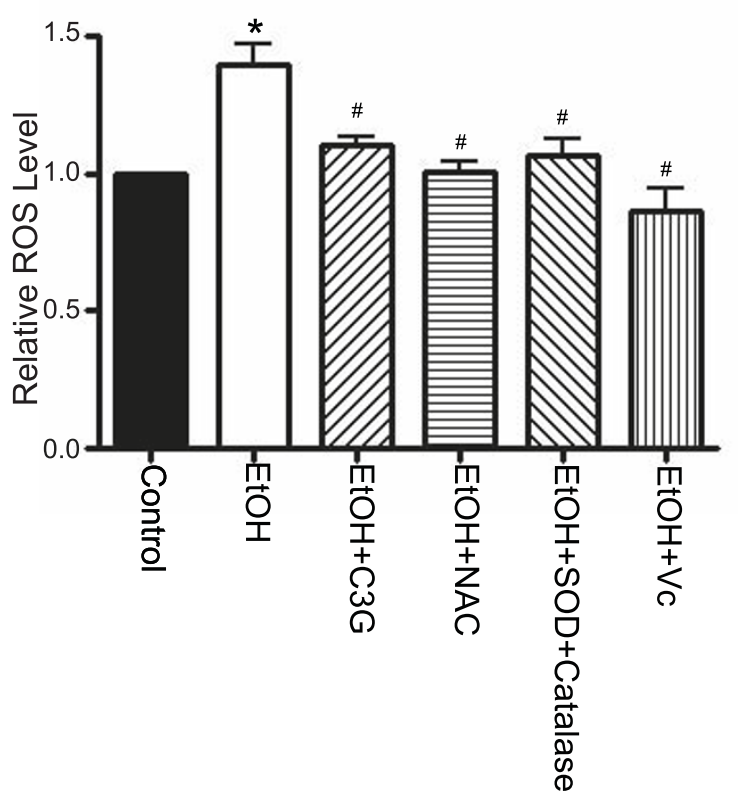

B

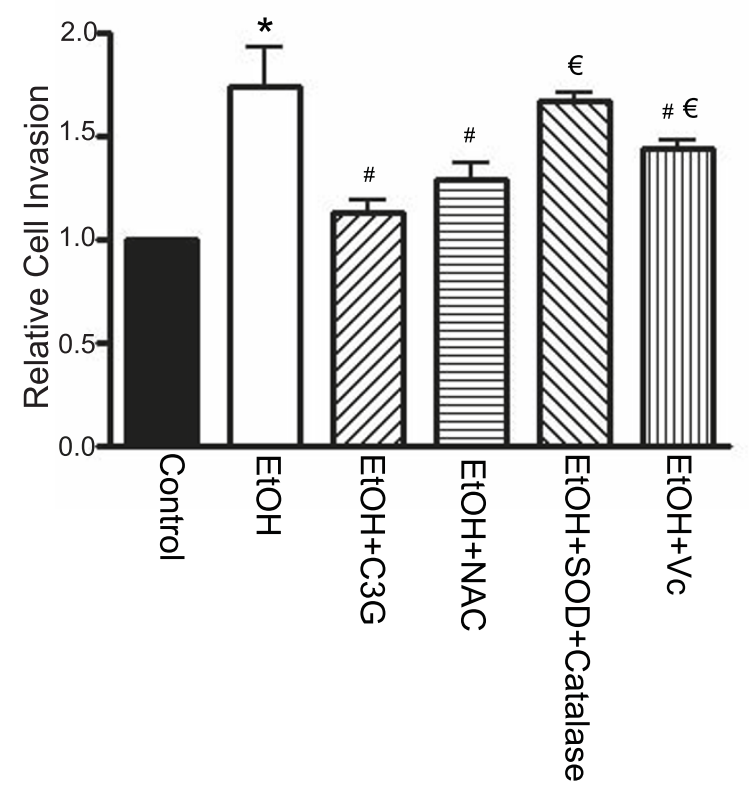

C

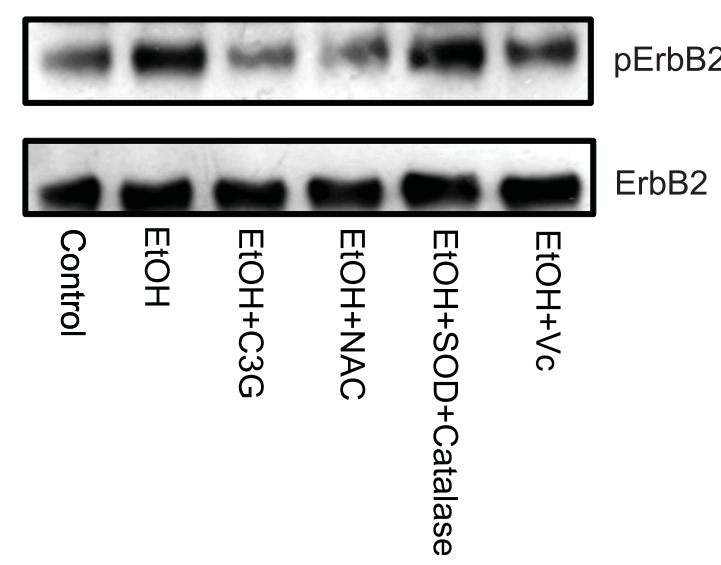

Figure 8 Effects of C3G and antioxidants on ethanol-induced ROS generation, cell invasion and ErbB2 phosphorylation. A: MCF7 ${ }^{\text {ErbB2 }}$ cells were exposed to ethanol (0 or $400 \mathrm{mg} / \mathrm{dl})$ with/without C3G $(10 \mu \mathrm{M})$, SOD $(50 \mathrm{U} / \mathrm{ml}) /$ catalase $(200 \mathrm{U} / \mathrm{ml})$, NAC (5 mM) or vitamin C (20 $\mu \mathrm{M})$ for $48 \mathrm{~h}$. Intracellular ROS levels were measured by flow cytometry as described under the Materials and Methods. B: The invasive potential of MCF7 ${ }^{\text {ErbB2 }}$ cells was evaluated as described above and expressed relative to untreated controls. C: The phosphorylation of ErbB2 in MCF7 ${ }^{\text {ErbB2 }}$ cells was analyzed with immunoblotting. The experiment was replicated three times. ${ }^{*}$ denotes a statistically significant difference from untreated controls. \# denotes a significant difference from ethanol-treated groups. \# denotes a significant difference from ethanol- and C3G-treated groups.

that had a similar ROS scavenging capacity as C3G. Superoxide dismutase (SOD) is a scavenger for $\mathrm{O}_{2}{ }^{*}$ and catalase is a scavenger for hydrogen peroxide $\left(\mathrm{H}_{2} \mathrm{O}_{2}\right)$. $\mathrm{N}$-aceytlcysteine (NAC) $(5 \mathrm{mM})$, vitamin $\mathrm{C}(20 \mu \mathrm{M})$ and SOD $(50 \mathrm{U} / \mathrm{ml})$ plus catalase $(200 \mathrm{U} / \mathrm{ml})$ had approximately the same antioxidant effect as C3G $(10 \mu \mathrm{M})$ (Figure 8A). As shown in Figure 8B, C3G most effectively inhibited ethanol-enhanced invasion of breast cancer cells; NAC and vitamin $\mathrm{C}$ also provided significant inhibition, but to a lesser extent. On the other hand, SOD plus catalase had little effect on ethanol-enhanced cell invasion. A similar result regarding the effect of C3G and other antioxidants on ethanol-induced ErbB2 phosphorylation was observed (Figure 8C). 


\section{Discussion}

\section{C3G as a potent agent to alleviate ethanol-induced cell migration/invasion}

In search for better chemopreventive or chemotherapeutic agents, we isolated a natural antioxidant cyanidin-3glucoside (C3G) from blackberries [14,32]. C3G is a member of the anthocyanin family which is present in various vegetables and fruits, especially edible berries. We have confirmed C3G's antioxidant property [14,23]. C3G has been implicated in some beneficial health actions including reducing age-associated oxidative stress, improving cognitive brain function, as well as anti-diabetic, anti-inflammation, anti-atherogenic and anti-obesity activity [33]. C3G exhibits anti-cancer properties in various in vitro and animal models of carcinogenesis and tumor development; the effects of C3G include the inhibition of tumor cell proliferation and the attenuation of cell migration/invasion as well as metastasis in vivo [13-18].

We demonstrate here that C3G inhibits ethanolmediated migration/invasion in cells expressing high levels of ErbB2. C3G has a greater inhibitory effect on the invasion of cells treated with $200 \mathrm{mg} / \mathrm{dl}$ ethanol compared to $400 \mathrm{mg} / \mathrm{dl}$ (Figure 1B); the underlying mechanism is unclear. C3G is effective at $10 \mu \mathrm{M}$, a concentration that is lower than previously reported for its anti-cancer effects. C3G inhibits the migration/invasion of A549 lung cancer cells at $40-100 \mu \mathrm{M}[14,34]$. It is unlikely that C3G-mediated inhibition of tumor cell migration/invasion in this study results from decreased cell viability. C3G up to $40 \mu \mathrm{M}$ does not affect the viability of breast cancer cells (Figure 1D). It is reported that C3G at $100 \mu \mathrm{M}$ fails to reduce the viability of A549 lung cancer cells [34]. However, at $20 \mu \mathrm{M}, \mathrm{C} 3 \mathrm{G}$ significantly decreases the viability of HS578T human breast cancer cells [13]. Thus, cells apparently display differential sensitivity to C3G. For BT474 cells, C3G does not have a dose-dependent inhibitory effect. It is likely BT474 cells are more sensitive to C3G and the concentration may need to be lower in order to see the dosedependent inhibition.

Consistent with its effects on migration/invasion, C3G affects early events associated with cell motility. C3G inhibits ethanol-mediated cell adhesion to the ECM, formation of focal adhesions and development of lamellipodia. These events are prerequisites for cell migration/ invasion. These results suggest that ethanol-induced migration/invasion is initiated by tumor cell/ECM interaction and C3G blocks this interaction.

\section{C3G and ethanol-stimulated cell signaling}

Ethanol-stimulated tumor cell/ECM interaction may be initiated by its effect on ErbB2 activity. Ethanol increases the phosphorylation of ErbB2 and enhances the adhesion of breast cancer cells with high levels of ErbB2 to the ECM as well as the assembly of focal adhesions in these cells [19]. These effects were not observed in breast cancer cells expressing low levels of ErbB2.

FAK is a critical regulator of cell/ECM interaction and is strongly implicated in tumor aggressiveness [35,36]. It has been shown that FAK is essential for ErbB2/ErbB3induced oncogenesis and breast cancer invasion [37]. The phosphorylation of FAK at Tyr 861 plays an important role in the invasion of breast cancer cells [38]. FAK is a substrate of cSrc. The activation of ErbB2 recruits cSrc and FAK, resulting in the phosphorylation of cSrc at Tyr 216 and FAK at Tyr 861 in breast cancer cells [39,40]. An ErbB2 inhibitor Tyrphostin (AG825) abolishes the ethanol-stimulated interaction between ErbB2 and FAK, as well as the adhesion of breast cancer cells to the ECM [41]. It appears C3G targets ErbB2 since C3G is able to inhibit ethanol-mediated phosphorylation of ErbB2, cSrc and FAK. Additionally, it inhibits the ethanol-mediated interaction among these proteins.

Previously we have shown that JNK activation is required in ethanol-induced migration/invasion of breast cancer cells [10]. It was reported that JNK activation during cell migration is mediated by $\mathrm{p} 130^{\mathrm{Cas}} / \mathrm{Crk}$ coupling or JSAP1 (JNK/stress-activated protein kinaseassociated protein 1)[42,43]. p130 ${ }^{\text {Cas }}$ (Crk-associated substrate) is an adaptor protein and it binds to and is phosphorylated by FAK in a FAK/cSrc dependent manner [27]. Activation of $\mathrm{p} 130^{\mathrm{Cas}}$ leads to recruitment of Crk to form an adaptor complex which results in activation of Rac1 and JNKs. We show here that ethanol increases the association of $\mathrm{p} 130^{\mathrm{Cas}}$ with $\mathrm{FAK} / \mathrm{CSrc}$ and the phosphorylation of $\mathrm{p} 130^{\mathrm{Cas}}$. Ethanol also promotes the association between p130 ${ }^{\mathrm{Cas}}$ and JNKs. C3G inhibits ethanol-mediated $\mathrm{p} 130^{\mathrm{Cas}} / \mathrm{JNK}$ interaction (Figure 5). Together, our results indicate that ethanol activates p130 ${ }^{\text {Cas }}$ and JNKs through the ErbB2/cSrc/FAK pathway. Blocking ErbB2/cSrc/FAK signaling by C3G inhibits ethanol-mediated activation of JNKs which is necessary for cell migration/invasion. At times the effect of C3G on cell signaling components, such as FAK, cSrc and JNK, is not dose-dependent, which is not entirely consistent with its effect on ethanol-induced cell migration/invasion. This suggests that the mechanism of ethanol-induced cell migration/invasion is complex and probably multiple signaling pathways are involved.

\section{Antioxidant property of C3G}

Ethanol exposure causes the accumulation of intracellular ROS $[10,23]$. The antioxidant property of C3G is confirmed in this study and we show that C3G effectively blocks ethanol-induced ROS production in breast 
cancer cells. ROS is reported to be involved in the activation of EGFR [44]. To evaluate the involvement of ROS, we compared the effect of C3G with other antioxidants. We have titrated antioxidants and identified concentrations for these antioxidants to produce a ROS scavenging capacity similar to C3G at $10 \mu \mathrm{M}$. Although these antioxidants have a similar capacity of scavenging ROS, they are less effective in alleviating ethanolinduced cell invasion and ErbB2 phosphorylation. Broad antioxidants, such as NAC and vitamin C, display modest inhibition on ethanol-induced cell invasion and ErbB2 phosphorylation, but to a lesser extent compared to C3G. More specific antioxidants, SOD (for superoxide) plus catalase (for hydrogen peroxide) fail to inhibit ethanol-stimulated invasion and ErbB2 phosphorylation. These data suggest that although the antioxidant property may be involved, C3G may also act through other mechanisms to regulate ErbB2 signaling and subsequent migration/invasion. We have previously shown that C3G is able to reverse ethanol-induced inhibition of neurite outgrowth in neuronal cells; however, its antioxidant property is minimally involved [23].

C3G has drawn increasing attention because of its potential anti-cancer properties. A recent animal study investigates the pharmacokinetics of C3G and demonstrates that pharmacologically relevant concentrations of C3G are achievable in vivo through oral administration or intravenous injection in mice without apparent adverse effects [45]. Further analysis suggests that concentrations required for in vivo action of C3G could be much lower than that of in vitro [14,45]. In future studies, we will evaluate the effect of C3G on ethanolinduced tumor promotion in animal models. C3G may offer a novel avenue for treating alcohol-related disorders.

\section{Abbreviations}

C3G: Cyanidin-3-glucoside; ECM: extracellular matrix; FAK: focal adhesion kinase; IP: Immunoprecipitation; JNKs: c-Jun N-terminal kinases; NAC: Nacetyl-cysteine; ROS: reactive oxygen species; SOD: superoxide dismutase.

\section{Acknowledgements}

This research was supported by grants from the National Institutes of Health (AA01540 and AA017226).

\section{Author details}

${ }^{1}$ Department of Internal Medicine, University of Kentucky College of Medicine, Lexington, KY 40536, USA. ²Pathophysiological Department, School of Basic Medicine, Anhui Medical University, Hefei, Anhui, PR China 230032. ${ }^{3}$ National Institute for Occupational Safety and Health, Morgantown, West Virginia 26505, USA. ${ }^{4}$ Beltsville Agricultural Research Center, U. S. Department of Agriculture, Beltsville, Maryland 20705, USA. ${ }^{5}$ Graduate Center for Toxicology, University of Kentucky, 232 Health Sciences Research Building, Lexington, Kentucky 40536, USA. Institute for Nutritional Sciences, Shanghai Institutes for Biological Sciences, Chinese Academy of Sciences, Shanghai, PR China 200031.

\section{Authors' contributions}

MX carried out the biochemical studies and participated in all experiments in this study. KB, JF and GC participated in assays for cell treatment, immunoblotting and ethanol exposure paradigm. MD, SW, XS, ZK and JL conceived of the study, and participated in its design and coordination and helped to draft the manuscript. All authors read and approved the final manuscript.

\section{Competing interests}

The authors declare that they have no competing interests.

Received: 20 July 2010 Accepted: 29 October 2010 Published: 29 October 2010

\section{References}

1. Key J, Hodgson S, Omar RZ, Jensen TK, Thompson SG, Boobis AR, Davies DS, Elliott P: Meta-analysis of studies of alcohol and breast cancer with consideration of the methodological issues. Cancer Causes Control 2006, 17:759-70.

2. Seitz HK, Maurer B: The relationship between alcohol metabolism, estrogen levels, and breast cancer risk. Alcohol Res Health 2007, 30:42-3.

3. Seitz HK, Becker P: Alcohol metabolism and cancer risk. Alcohol Res Health 2007, 30:38-7.

4. Tjonneland A, Christensen J, Olsen A, Stripp C, Thomsen BL, Overvad K, Peeters PH, van Gils CH, Bueno-de-Mesquita HB, Ocke MC, Thiebaut A, Fournier A, Clavel-Chapelon F, Berrino F, Palli D, Tumino R, Panico S, Vineis P, Agudo A, Ardanaz E, Martinez-Garcia C, Amiano P, Navarro C, Quiros JR, Key TJ, Reeves G, Khaw KT, Bingham S, Trichopoulou A, Trichopoulos D, Naska A, Nagel G, Chang-Claude J, Boeing H, Lahmann PH, Manjer J, Wirfalt E, Hallmans G, Johansson I, Lund E, Skeie G, Hjartaker A, Ferrari P, Slimani N, Kaaks R, Riboli E: Alcohol intake and breast cancer risk: the European Prospective Investigation into Cancer and Nutrition (EPIC). Cancer Causes Control 2007, 18:361-73.

5. Visvanathan K, Crum RM, Strickland PT, You X, Ruczinski I, Berndt SI, Alberg AJ, Hoffman SC, Comstock GW, Bell DA, Helzlsouer KJ: Alcohol dehydrogenase genetic polymorphisms, low-to-moderate alcohol consumption, and risk of breast cancer. Alcohol Clin Exp Res 2007, 31:467-76.

6. Vaeth PA, Satariano WA: Alcohol consumption and breast cancer stage at diagnosis. Alcohol Clin Exp Res 1998, 22:928-34.

7. Weiss HA, Brinton LA, Brogan D, Coates RJ, Gammon MD, Malone KE, Schoenberg JB, Swanson CA: Epidemiology of in situ and invasive breast cancer in women aged under 45. Br J Cancer 1996, 73:1298-305.

8. Aye MM, Ma C, Lin H, Bower KA, Wiggins RC, Luo J: Ethanol-induced in vitro invasion of breast cancer cells: the contribution of MMP-2 by fibroblasts. Int J Cancer 2004, 112:738-46.

9. Ke Z, Lin H, Fan Z, Cai TQ, Kaplan RA, Ma C, Bower KA, Shi X, Luo J: MMP-2 mediates ethanol-induced invasion of mammary epithelial cells overexpressing ErbB2. Int J Cancer 2006, 119:8-16.

10. Ma C, Lin H, Leonard SS, Shi X, Ye J, Luo J: Overexpression of ErbB2 enhances ethanol-stimulated intracellular signaling and invasion of human mammary epithelial and breast cancer cells in vitro. Oncogene 2003, 22:5281-90.

11. Paterson MC, Dietrich KD, Danyluk J, Paterson AH, Lees AW, Jamil N, Hanson J, Jenkins H, Krause BE, McBlain WA: Correlation between c-erbB-2 amplification and risk of recurrent disease in node-negative breast cancer. Cancer Res 1991, 51:556-67.

12. Slamon DJ, Clark GM, Wong SG, Levin WJ, Ullrich A, McGuire WL: Human breast cancer: correlation of relapse and survival with amplification of the HER-2/neu oncogene. Science 1987, 235:177-82.

13. Chen PN, Chu SC, Chiou HL, Chiang CL, Yang SF, Hsieh YS: Cyanidin 3glucoside and peonidin 3-glucoside inhibit tumor cell growth and induce apoptosis in vitro and suppress tumor growth in vivo. Nutr Cancer 2005, 53:232-43.

14. Ding $M$, Feng $R$, Wang SY, Bowman L, Lu Y, Qian Y, Castranova V, Jiang BH, Shi X: Cyanidin-3-glucoside, a natural product derived from blackberry, exhibits chemopreventive and chemotherapeutic activity. J Biol Chem 2006, 281:17359-68.

15. Shih PH, Yeh CT, Yen GC: Effects of anthocyanidin on the inhibition of proliferation and induction of apoptosis in human gastric adenocarcinoma cells. Food Chem Toxicol 2005, 43:1557-66.

16. Zhang Y, Vareed SK, Nair MG: Human tumor cell growth inhibition by nontoxic anthocyanidins, the pigments in fruits and vegetables. Life Sci 2005, 76:1465-72. 
17. Fukamachi K, Imada T, Ohshima Y, Xu J, Tsuda H: Purple corn color suppresses Ras protein level and inhibits 7,12-dimethylbenz[a] anthracene-induced mammary carcinogenesis in the rat. Cancer Sci 2008, 99:1841-6.

18. Zhang $Y$, Seeram NP, Lee R, Feng $L$, Heber D: Isolation and identification of strawberry phenolics with antioxidant and human cancer cell antiproliferative properties. J Agric Food Chem 2008, 56:670-5.

19. Xu M, Bower KA, Chen G, Shi X, Dong Z, Ke Z, Luo J: Ethanol enhances the interaction of breast cancer cells over-expressing ErbB2 with fibronectin. Alcohol Clin Exp Res 2010, 34:751-60.

20. Grimaldi C, Pisanti S, Laezza C, Malfitano AM, Santoro A, Vitale M, Caruso MG, Notarnicola M, lacuzzo I, Portella G, Di M, Bifulco M: Anandamide inhibits adhesion and migration of breast cancer cells. Exp Cell Res 2006, 312:363-73.

21. Wang F, Nohara K, Olivera A, Thompson EW, Spiegel S: Involvement of focal adhesion kinase in inhibition of motility of human breast cancer cells by sphingosine 1-phosphate. Exp Cell Res 1999, 247:17-28.

22. Xu M, Waters $\mathrm{CL}, \mathrm{Hu} C$, Wysolmerski RB, Vincent PA, Minnear FL: Sphingosine 1-phosphate rapidly increases endothelial barrier function independently of VE-cadherin but requires cell spreading and Rho kinase. Am J Physiol Cell Physiol 2007, 293:C1309-C1318.

23. Chen G, Bower KA, Xu M, Ding M, Shi X, Ke ZJ, Luo J: Cyanidin-3-glucoside reverses ethanol-induced inhibition of neurite outgrowth: role of glycogen synthase kinase 3 Beta. Neurotox Res 2009, 15:321-31.

24. Vadlamudi RK, Sahin AA, Adam L, Wang RA, Kumar R: Heregulin and HER2 signaling selectively activates c-Src phosphorylation at tyrosine 215. FEBS Lett 2003, 543:76-80.

25. Dolfi F, Garcia-Guzman M, Ojaniemi M, Nakamura H, Matsuda M, Vuori K: The adaptor protein Crk connects multiple cellular stimuli to the JNK signaling pathway. Proc Natl Acad Sci USA 1998, 95:15394-9.

26. Klemke RL, Leng J, Molander R, Brooks PC, Vuori K: Cheresh DA, CAS/Crk coupling serves as a "molecular switch" for induction of cell migration. $J$ Cell Biol 1998, 140:961-72.

27. Cox BD, Natarajan M, Stettner MR, Gladson CL: New concepts regarding focal adhesion kinase promotion of cell migration and proliferation. $J$ Cell Biochem 2006, 99:35-52.

28. Huang C, Jacobson K, Schaller MD: MAP kinases and cell migration. J Cell Sci 2004, 117:4619-28.

29. Yamaguchi H, Wyckoff J, Condeelis J: Cell migration in tumors. Curr Opin Cell Biol 2005, 17:559-64.

30. Turner CE: Paxillin interactions. J Cell Sci 2000, 113(Pt 23):4139-40.

31. Chen G, Ma C, Bower KA, Shi X, Ke Z, Luo J: Ethanol promotes endoplasmic reticulum stress-induced neuronal death: involvement of oxidative stress. J Neurosci Res 2008, 86:937-46.

32. Zheng W, Wang SY: Oxygen radical absorbing capacity of phenolics in blueberries, cranberries, chokeberries, and lingonberries. J Agric Food Chem 2003, 51:502-9.

33. Chen G, Luo J: Anthocyanins: are they beneficial in treating ethanol neurotoxicity? Neurotox Res 2010, 17:91-101.

34. Chen PN, Kuo WH, Chiang CL, Chiou HL, Hsieh YS, Chu SC: Black rice anthocyanins inhibit cancer cells invasion via repressions of MMPs and u-PA expression. Chem Biol Interact 2006, 163:218-29.

35. Hao H, Naomoto Y, Bao X, Watanabe N, Sakurama K, Noma K, Motoki T, Tomono Y, Fukazawa T, Shirakawa Y, Yamatsuji T, Matsuoka J, Wang ZG, Takaoka M: Focal adhesion kinase as potential target for cancer therapy (Review). Oncol Rep 2009, 22:973-9.

36. Schwock J, Dhani N, Hedley DW: Targeting focal adhesion kinase signaling in tumor growth and metastasis. Expert Opin Ther Targets 2010, 14:77-94.

37. Benlimame N, He Q, Jie S, Xiao D, Xu YJ, Loignon M, Schlaepfer DD, AlaouiJamali MA: FAK signaling is critical for ErbB-2/ErbB-3 receptor cooperation for oncogenic transformation and invasion. J Cell Biol 2005 171:505-16.

38. Earley S, Plopper GE: Phosphorylation of focal adhesion kinase promotes extravasation of breast cancer cells. Biochem Biophys Res Commun 2008, 366:476-82.

39. Vadlamudi RK, Sahin AA, Adam L, Wang RA, Kumar R: Heregulin and HER2 signaling selectively activates c-Src phosphorylation at tyrosine 215 . FEBS Lett 2003, 543:76-80
40. Vadlamudi RK, Adam L, Nguyen D, Santos M, Kumar R: Differential regulation of components of the focal adhesion complex by heregulin: role of phosphatase SHP-2. J Cell Physiol 2002, 190:189-99.

41. Xu M, Bower KA, Chen G, Shi X, Dong Z, Ke Z, Luo J: Ethanol Enhances the Interaction of Breast Cancer Cells Over-Expressing ErbB2 With Fibronectin. Alcohol Clin Exp Res 2010, 34(5):751-60.

42. Klemke RL, Leng J, Molander R, Brooks PC, Vuori K, Cheresh DA: CAS/Crk coupling serves as a "molecular switch" for induction of cell migration. $J$ Cell Biol 1998, 140:961-72.

43. Takino T, Nakada M, Miyamori H, Watanabe Y, Sato T, Gantulga D, Yoshioka K, Yamada KM, Sato H: JSAP1/JIP3 cooperates with focal adhesion kinase to regulate c-Jun $\mathrm{N}$-terminal kinase and cell migration. $J$ Biol Chem 2005, 280:37772-81.

44. von Montfort C, Fernau NS, Beier JI, Sies H, Klotz LO: Extracellular generation of hydrogen peroxide is responsible for activation of EGF receptor by ultraviolet A radiation. Free Radic Biol Med 2006, 41:1478-87.

45. Marczylo TH, Cooke D, Brown K, Steward WP, Gescher AJ: Pharmacokinetics and metabolism of the putative cancer chemopreventive agent cyanidin-3-glucoside in mice. Cancer Chemother Pharmacol 2009, 64:1261-8.

doi:10.1186/1476-4598-9-285

Cite this article as: Xu et al:: Cyanidin-3-Glucoside inhibits ethanolinduced invasion of breast cancer cells overexpressing ErbB2. Molecular Cancer 2010 9:285.

\section{Submit your next manuscript to BioMed Central and take full advantage of:}

- Convenient online submission

- Thorough peer review

- No space constraints or color figure charges

- Immediate publication on acceptance

- Inclusion in PubMed, CAS, Scopus and Google Scholar

- Research which is freely available for redistribution

Submit your manuscript at www.biomedcentral.com/submit
C) Biomed Central 